\title{
PENGETAHUAN, SIKAP, DAN PRAKTEK GIZI IBU PESERTA POSYANDU
}

(Nutritional Knowledge, Attitude and Practice of Posyandu Participants) Ali Khomsan ${ }^{1 *}$, Faisal Anwar ${ }^{1}$, dan Eddy S. Mudjajanto ${ }^{1}$

$1^{1^{*}}$ Alamat korespondensi: Departemen Gizi Masyarakat, Fakultas Ekologi Manusia, Institut Pertanian Bogor, Bogor 16680. Telp: 0251-8621258; Fax: 0251-8622276; Email: erlangga259@yahoo.com

1 Departemen Gizi Masyarakat, Fakultas Ekologi Manusia, Institut Pertanian Bogor, Bogor 16680

\begin{abstract}
Nutritional knowledge and attitude of mothers are required to improve children feeding patterns so that adequate nutrition for the children is reached, and in this way they can grow and develop well. The objectives of this action research were: (1) to assess mother nutritional knowledge, and (2) to evaluate the effects of nutrition education to the nutritional knowledge, attitude and practice (KAP) of mother. The research was carried out in two sub-districts of Bogor: Sub-District of Ciomas and Sub-District of Darmaga. This research started with a preliminary study as the first step and experimental design as the second step. As many as 16 posyandu that met research requirements were obtained. A total number of 240 mothers had been divided into kontrol and intervention groups. Collected data included the data of posyandu, household, children and mothers. Baseline data were collected during the pre-study, while end-line data were collected after conducting intervention (experiment). An experiment was made to determine the effect of nutrition education and home gardening on respond variables: mother's nutritional knowledge, attitude, and practice. The experiment had been conducted for five months in the form of providing nutrition education once in two weeks and implementing home gardening. Based on the General Linear Model (GLM) analysis, the intervention in the forms of nutrition education as well as home gardening programs which were carried for five months had a significant effect on the response variables (nutritional knowledge, attitude and practices among mothers.
\end{abstract}

Keywords: nutritional knowledge, attitude, practice, posyandu

\section{PENDAHULUAN}

Kemiskinan merupakan akar masalah terhadap munculnya masalah gizi di Indonesia, meskipun faktor lain juga turut berperan, seperti pengetahuan, budaya, kebiasaan makan, dan lainnya. Hal ini menjadi lebih buruk dengan rendahnya pengetahuan gizi dan minimnya upaya dalam menerapkan pengetahuan tersebut dalam kehidupan sehari-hari. Tingkat ekonomi seseorang yang tinggi bukan jaminan status gizi yang baik, tanpa adanya pengetahuan gizi yang baik. Pendidikan ibu merupakan faktor penting dan berhubungan dengan kualitas pengasuhan anak (Kardjati dkk, 1985). Level pendidikan formal yang tinggi tanpa disertai pengetahuan gizi yang cukup dapat mempengaruhi seseorang dalam memilih makanan untuk keluarga (Sediaoetama, 1996).

Sikap dan pengetahuan gizi ibu dibutuhkan untuk memperbaiki pola makan anak agar kecukupan gizi anak terpenuhi, dan dengan cara ini mereka dapat tumbuh dan berkembang dengan baik. Pengetahuan gizi ibu yang dipraktekkan dalam kehidupan sehari-hari memiliki pengaruh yang besar terhadap kondisi gizi keluarga (Suhardjo, 1989). Praktek pemberian makan pada anak memiliki pengaruh yang kuat terhadap kesehatan dan status gizinya. Kemampuan seorang ibu untuk memperkenalkan makanan baru pada anak memiliki pengaruh yang besar terhadap daya terima dan kesukaan anak terhadap suatu makanan.

Peserta atau ibu yang mengikuti kegiatan posyandu di Indonesia umumnya memiliki pendidikan yang rendah karena keterbatasan akses terhadap media untuk menambah pengetahuan gizi. Untuk itu, kegiatan yang dapat memberikan pendidikan gizi kepada ibu, akan sangat penting dan bermanfaat. Dengan ditingkatkannya pengetahuan gizi ibu, diharapkan mereka dapat menerapkannya untuk perbaikan pola makan anak, serta mencegah risiko terjadinya malnutrisi.

Tujuan yang ingin dicapai dalam penelitian ini adalah menilai pengetahuan gizi ibu dan mengevaluasi pengaruh pendidikan gizi 
terhadap pengetahuan, sikap dan praktek gizi ibu.

\section{METODE}

\section{Desain, Tempat dan Waktu Penelitian}

Desain yang digunakan dalam penelitian adalah eksperimental. Kegiatan diawali dengan penelitian pendahuluan. Lokasi kegiatan penelitian ini di dua kecamatan di Bogor: Kecamatan Ciomas dan Kecamatan Darmaga (Pada kedua tempat tersebut terdapat kelompok kontrol dan kelompok intervensi). Pendidikan gizi dilaksanakan selama 5 bulan dengan frekuensi 2 kali dalam sebulan. Tiap pertemuan berlangsung sekitar 60 - 90 menit.

\section{Penarikan Contoh}

Posyandu dijadikan sebagai unit percobaan. Setiap unit percobaan terdiri dari 15 rumahtangga (15 ibu dan 15 anak) yang memperoleh pendidikan gizi dan pemanfaatan pekarangan. Dengan menggunakan $\alpha=0.05$, kuasa uji $1-\beta=0.95, \quad \sigma=0.6$ dan $\delta=3$, dan dimasukkan ke dalam rumus berikut, menjadi

$\mathrm{n}=\frac{\left(\mathrm{z}_{0.05}+\mathrm{z}_{0.05}\right)^{2} 2 \times 1.2^{2}}{\mathbf{3}^{2}}=\frac{(1.64+1.64)^{2} 2 \times 1.2^{2}}{3^{2}}$

$\mathrm{n}=3.442688$ atau dibulatkan menjadi $\mathrm{n} \approx 4$

Menurut hasil perhitungan di atas, penelitian ulangan dilakukan empat kali untuk kedua perlakuan dan kontrol. Jumlah unit penelitian yang dibutuhkan ditunjukkan sebagai berikut:

Jumlah unit penelitian $=$ jumlah kelompok $\times$ jumlah perlakuan $\times$ ulangan $=2 \times 2 \times 4=16$ posyandu atau unit penelitian.

Karena setiap unit terdiri dari 15 ibu maka jumlah total ibu yang dibutuhkan adalah 240 orang.

\section{J enis dan Cara Pengumpulan Data}

Data yang dikumpulkan meliputi data pengetahuan gizi, sikap dan praktek gizi (KAP). Data baseline dikumpulkan selama penelitian pendahuluan, sedangkan data endline dikumpulkan setelah penelitian dilaksanakan. Pengumpulan data dilakukan dengan wawancara menggunakan kuesioner.

\section{Pengolahan dan Analisis Data}

Pengolahan data meliputi entry, editing, penggabungan lembar kerja, dan generating variables. Data dalam bentuk Excel diimport dari Statistical Analysis System (SAS), kemudian menjadi file SAS. Analisis data ini terma- suk perhitungan mean, standar deviasi, nilai minimum, nilai maksimum dan proporsi. Hasil perhitungan kemudian disajikan dalam bentuk tabel dan diagram. Analisis General Linear Model (GLM) untuk peubah: pengetahuan gizi, sikap, dan praktek gizi ibu dan kader digunakan program SAS. Analisis ini menguji pengaruh intervensi pendidikan gizi plus pemanfaatan pekarangan sebagai faktor peubah.

\section{HASIL DAN PEMBAHASAN}

\section{Pengetahuan Gizi}

Pengetahuan gizi merupakan prasyarat penting untuk terjadinya perubahan sikap dan perilaku gizi. Pengetahuan gizi yang baik akan mendorong ibu untuk mempraktekkan pemberian makan yang baik bagi anak-anaknya.

Berdasarkan penelitian, dari 20 item pertanyaan gizi ada tiga pertanyaan yang dapat dijawab dengan baik yaitu: (1) salah satu masalah gizi di Indonesia adalah Kurang Energi Protein, (2) penyebab kurang gizi adalah kemiskinan dan (3) mencuci tangan sebelum makan adalah termasuk menjaga sanitasi perseorangan. Pada kelompok kontrol banyak terjadi penurunan jumlah ibu yang menjawab benar (pertanyaan pengetahuan gizi). Ini berarti data endline justru lebih buruk daripada data baseline. Sebaliknya pada kelompok intervensi, jumlah ibu yang menjawab benar pada endline lebih banyak daripada baseline. Jadi, terdapat pengaruh positif intervensi penyuluhan gizi untuk setiap item pertanyaan pengetahuan gizi yang diajukan.

Tabel 1 menunjukkan skor pengetahuan gizi ibu pada kelompok kontrol dan intervensi. Pada kedua kelompok tersebut, skor pengetahuan gizi tergolong rendah $(<60)$. Pada kelompok kontrol, terjadi penurunan skor pengetahuan gizi sebesar -2.3. Pada kelompok intervensi, terjadi peningkatan skor sebesar 7.5. Peningkatan ini, sebenarnya masih belum terlalu tinggi. Kalau kita gunakan cut off point 60.0 sebagai batas pengetahuan gizi rendah, maka baik skor baseline maupun endline pada kedua kelompok masih tergolong dalam pengetahuan gizi rendah. Kelompok intervensi menunjukkan skor yang lebih baik dibandingkan dengan kelompok kontrol. Efek bersih peningkatan skor pengetahuan gizi pada kelompok intervensi adalah 9.8 point.

Tabel 2 menunjukkan sebaran skor pengetahuan gizi setelah diklasifikasikan dalam 
kategori kurang $(<60)$, cukup (60-79), dan baik $(\geq 80)$. Tabel tersebut menjelaskan bahwa cukup banyak ibu pada kelompok kontrol yang memiliki skor pengetahuan gizi dengan kategori kurang, baik pada saat pengumpulan data baseline maupun endline. Terdapat $71.7 \%$ (baseline) dan $70.0 \%$ (endline) ibu dengan skor pengetahuan gizi <60. Keadaan lebih baik dijumpai pada kelompok intervensi dimana data baseline menunjukkan sejumlah $60.8 \%$ ibu berpengetahuan gizi kurang, dan pada saat endline jumlah mereka yang berpengetahuan gizi kurang turun menjadi $44.2 \%$. Hal ini menunjukkan adanya dampak positif penyuluhan gizi yang dilakukan selama lima bulan.

Jumlah ibu dengan skor pengetahuan gizi sedang (skor 60-79) pada kelompok kontrol adalah 24.2\% (baseline) dan 23.3\% (endline). Hal ini menunjukkan bahwa dalam rentang waktu 5 bulan tidak ada perubahan yang berarti pada kelompok kontrol. Pada kelompok intervensi, terjadi perubahan yaitu ibu-ibu berpengetahuan gizi sedang berkurang dari 29.2\% (baseline) menjadi 21.7\% (endline).

Jumlah ibu dengan kategori pengetahuan gizi baik (skor $\geq 80$ ) pada kelompok kontrol adalah 4.2\% (baseline) dan 6.7\% (endline), atau dengan kata lain terjadi sedikit peningkatan. Pada kelompok intervensi peningkatannya lebih besar yakni dari $10.0 \%$ (baseline) menjadi 34.2\% (endline). Jadi secara keseluruhan dapat dikatakan bahwa intervensi penyuluhan gizi telah dapat mengurangi ibu yang berpengetahuan gizi kurang, dan di sisi lain meningkatkan jumlah ibu berpengetahuan gizi baik.

\section{Sikap Gizi}

Sikap gizi merupakan kecenderungan seseorang untuk menyetujui atau tidak menyetujui terhadap suatu pernyataan (statement) yang diajukan terkait dengan pangan dan gizi. Sikap gizi seringkali terkait erat dengan penge- tahuan gizi yaitu jika memiliki pengetahuan gizi baik maka cenderung sikap gizi baik pula.

Berdasarkan pertanyaan mengenai sikap gizi, sebagian besar responden telah memiliki sikap gizi positif, baik pada kelompok kontrol maupun intervensi. Pada kelompok kontrol lebih banyak dijumpai delta negatif artinya kondisi baseline lebih baik daripada endline, atau dengan kata lain sikap gizi saat baseline lebih baik daripada saat endline. Sebaliknya pada kelompok intervensi, sikap gizi saat endline lebih baik daripada saat baseline. Hal ini menunjukkan adanya dampak positif penyuluhan gizi. Penyuluhan gizi menyebabkan semakin banyaknya ibu-ibu yang memiliki sikap gizi positif.

Ibu-ibu menyatakan bahwa konsumsi pangan ibu hamil sebaiknya sama saja dengan ibu yang tidak hamil. Hal ini tidak sesuai dengan anjuran gizi yang menyarankan asupan gizi lebih banyak untuk ibu hamil, agar tumbuh kembang janin lebih optimal. Terkait dengan pemeriksaan kehamilan, ibu-ibu menyatakan bahwa pemeriksaan cukup dilakukan saat mendekati kehamilan 9 bulan. Padahal, pemeriksaan kehamilan dianjurkan minimal empat kali selama kehamilan.

Tabel 3 menunjukkan skor sikap gizi ibu baik pada kelompok kontrol maupun intervensi. Apabila kita bandingkan data baseline dan endline, tampak bahwa pada kelompok kontrol terjadi penurunan skor sikap gizi dari 73.8 menjadi 70.2 (turun 3.7). Sebaliknya pada kelompok intervensi, terjadi peningkatan skor sikap gizi dari 71.8 menjadi 76.9 (naik 5.1). Dalam hal sikap gizi ini, intervensi penyuluhan gizi yang dilakukan dapat memperbaiki sikap gizi dengan efek bersih 8.8 point.

Tabel 4 menunjukkan sebaran sikap gizi setelah dikategorikan dalam klasifikasi kurang $(<60)$, sedang (60-79), dan baik $(\geq 80)$.

Tabel 1. Sebaran Statistik Skor Pengetahuan Gizi Ibu

\begin{tabular}{lcc}
\hline \multicolumn{1}{c}{ Pengetahuan Gizi lbu } & Kontrol & Intervensi \\
\hline Baseline Data & $37.1 \pm 23.7$ & $46.0 \pm 25.1$ \\
Endline Data & $34.9 \pm 27.4$ & $53.6 \pm 33.5$ \\
Delta & $-2.3 \pm 18.2$ & $7.5 \pm 18.9$ \\
\hline
\end{tabular}

Tabel 2. Sebaran Kategori Skor Pengetahuan Gizi Ibu

\begin{tabular}{cccccc}
\hline \multirow{2}{*}{ Rata-Rata Skor } & \multirow{2}{*}{ Kategori } & \multicolumn{2}{c}{ Kontrol } & \multicolumn{2}{c}{ Intervensi } \\
\cline { 3 - 6 } & & Awal (\%) & Akhir (\%) & Awal (\%) & Akhir (\%) \\
\hline$<60$ & Kurang & 71.7 & 70.0 & 60.8 & 44.2 \\
$60-79$ & Sedang & 24.2 & 23.3 & 29.2 & 21.7 \\
$\geq 80$ & Baik & 4.2 & 6.7 & 10.0 & 34.2 \\
\hline
\end{tabular}


Tabel 3. Sebaran Statistik Sikap Gizi Ibu

\begin{tabular}{lcc}
\hline Sikap Gizi Ibu & Kontrol & Intervensi \\
\hline Baseline Data & $73.8 \pm 16.7$ & $71.8 \pm 18.1$ \\
Endline Data & $70.2 \pm 24.8$ & $76.9 \pm 22.3$ \\
Delta & $-3.7 \pm 24.9$ & $5.1 \pm 21.7$ \\
\hline
\end{tabular}

Pada kelompok kontrol, antara data baseline dan end-line tidak menunjukkan perubahan yang berarti. Sebaliknya pada kelompok intervensi, jumlah ibu dengan sikap gizi baik meningkat $13.4 \%$. Jadi, Tabel 4 menunjukkan semakin menguatkan peran intervensi penyuluhan gizi yang dilakukan terhadap perbaikan sikap gizi.

\section{Praktek Gizi}

Tabel 5 menunjukkan sebaran anggota keluarga yang biasa sarapan pagi. Dibandingkan ayah atau ibu, jumlah anak yang biasa sarapan pagi lebih banyak, baik pada kelompok kontrol ataupun intervensi. Pada kelompok kontrol maupun intervensi jumlah ayah, ibu, dan anak yang biasa sarapan pagi umumnya relatif tinggi. Apabila dibandingkan data baseline dan endline terlihat adanya penurunan, artinya jumlah yang sarapan pagi pada saat endline data dikumpulkan lebih rendah dibandingkan saat baseline. Penurunan kebiasaan sarapan pagi lebih tinggi pada kelompok kontrol daripada kelompok intervensi.

Sarapan pagi adalah bekal untuk melakukan aktivitas sepanjang pagi-siang. Paling ti- dak ada dua manfaat pentingnya sarapan pagi. Pertama, sarapan pagi dapat menyediakan karbohidrat yang siap digunakan untuk meningkatkan kadar gula darah. Dengan kadar gula darah yang terjamin normal, maka gairah dan aktivitas kegiatan fisik dapat dilakukan dengan baik. Kedua, pada dasarnya sarapan pagi akan memberikan kontribusi penting akan beberapa zat gizi yang diperlukan tubuh seperti protein, lemak, vitamin, dan mineral. Ketersediaan zat gizi ini bermanfaat untuk berfungsinya proses fisiologis dalam tubuh.

Melewatkan sarapan pagi akan menyebabkan tubuh kekurangan glukosa dan hal ini menyebabkan tubuh lemah dan kurang konsentrasi karena tiadanya suplai energi. Jika hal ini terjadi, maka tubuh akan membongkar persediaan tenaga yang ada dari jaringan lemak tubuh. Tidak sarapan pagi menyebabkan kekosongan lambung selama 10-11 jam karena mekanan terakhir yang masuk ke tubuh seseorang adalah saat makan malam.

Tabel 6 menunjukkan sebaran anggota keluarga yang biasa makan tiga kali setiap hari. Umumnya anak lebih banyak yang makan 3 kali sehari dibandingkan orang tuanya. Data endline menunjukkan adanya penurunan anggota keluarga yang makan tiga kali, namun persentase penurunan relatif lebih rendah pada kelompok intervensi. Di pedesaan, banyak orang yang makan dua kali sehari karena sudah merupakan kebiasaan. Dalam penelitian ini

Tabel 4. Sebaran Kategori Skor Sikap Gizi

\begin{tabular}{|c|c|c|c|c|c|c|c|c|c|}
\hline \multirow{3}{*}{ Rata-Rata Skor } & \multirow{3}{*}{ Kategori } & \multicolumn{4}{|c|}{ Kontrol } & \multicolumn{4}{|c|}{ Intervensi } \\
\hline & & \multicolumn{2}{|c|}{ Awal } & \multicolumn{2}{|c|}{ Akhir } & \multicolumn{2}{|c|}{ Awal } & \multicolumn{2}{|c|}{ Akhir } \\
\hline & & $\mathbf{n}$ & $\%$ & $\mathbf{n}$ & $\%$ & $n$ & $\%$ & $\mathbf{n}$ & $\%$ \\
\hline$<60$ & Kurang & 12 & 10.0 & 16 & 13.3 & 16 & 13.3 & 8 & 6.7 \\
\hline $60-79$ & Cukup & 44 & 36.7 & 39 & 32.5 & 40 & 33.3 & 32 & 26.7 \\
\hline$\geq 80$ & Baik & 64 & 53.3 & 65 & 54.2 & 64 & 53.3 & 80 & 66.7 \\
\hline
\end{tabular}

Tabel 5. Statistik Anggota Keluarga Ibu Balita yang Biasa Sarapan Pagi

\begin{tabular}{cccccccc}
\hline \multirow{2}{*}{ Keluarga Ibu Balita yang Sarapan Pagi } & \multicolumn{3}{c}{ Kontrol } & \multicolumn{3}{c}{ Intervensi } \\
\cline { 2 - 7 } & Awal (\%) & Akhir (\%) & Delta (\%) & Awal (\%) & Akhir (\%) & Delta (\%) \\
\hline - Ayah & 75.0 & 63.3 & -11.7 & 75.8 & 72.5 & -3.3 \\
- Ibu & 75.0 & 69.2 & -5.8 & 81.7 & 80.0 & -1.7 \\
- Anak & 91.6 & 77.5 & -14.1 & 92.5 & 83.3 & -9.2 \\
- Lainnya & 3.3 & 2.5 & -0.8 & 6.7 & 2.5 & -4.2 \\
\hline
\end{tabular}

Tabel 6. Statistik Anggota Keluarga Ibu Balita yang Makan 3 Kali

\begin{tabular}{lcccccc}
\hline \multirow{2}{*}{$\begin{array}{c}\text { keluarga Ibu Balita yang Biasa } \\
\text { Makan 3 kali }\end{array}$} & \multicolumn{3}{c}{ Kontrol } & \multicolumn{3}{c}{ Intervensi } \\
\cline { 2 - 7 } & Awal & Akhir & Delta & Awal & \multicolumn{1}{c}{ Akhir } & Delta \\
\cline { 2 - 7 } & $\%$ & $\%$ & $\%$ & $\%$ & $\%$ & $\%$ \\
\hline - Ayah & 49.2 & 42.5 & -6.7 & 56.7 & 50.4 & -6.3 \\
- Ibu & 55.8 & 45.0 & -10.8 & 60.8 & 59.2 & -1.6 \\
- Anak & 65.8 & 55.8 & -10.0 & 62.5 & 63.3 & 0.8 \\
- Lainnya & 3.3 & 0.8 & -2.5 & 7.6 & 0.0 & -7.6 \\
\hline
\end{tabular}


juga terlihat masih cukup banyak anggota masyarakat yang tidak makan 3 kali sehari. Mungkin besaran persentasenya sekitar $30-40 \%$. Frekuensi makan 2 kali sehari, akan mengurangi peluang seseorang untuk tercukupi kebutuhan gizinya. Sarapan pagi adalah yang biasanya ditinggalkan dan seringkali sarapan pagi dianggap kurang mendatangkan selera.

Tabel 7 menunjukkan kebiasaan minum susu di kalangan anggota keluarga. Anak-anak di bawah usia 5 tahun biasanya yang paling diutamakan untuk minum susu. Hal ini terlihat pada tabel, dimana umumnya lebih dari 50\% anak-anak balita terbiasa minum susu. Sebagian anggota keluarga juga minum susu, namun persentasenya lebih sedikit. Pada kelompok intervensi, dengan memperhatikan data baseline dan endline, terlihat adanya sedikit peningkatan jumlah anggota rumah tangga yang minum susu. Pada kelompok control, justru terjadi penurunan.

Saat ini konsumsi susu di tingkat masyarakat masih sangat rendah. Rata-rata populasi di Indonesia minum susu setara 7 liter per kapita per tahun, suatu jumlah yang sangat sedikit dibandingkan beberapa negara Asia lainnya. Konsumsi susu yang rendah terkait dengan harga susu yang mahal dan daya beli masyarakat yang rendah. Oleh sebab itu, dapat dimengerti bila konsumsi susu lebih diutamakan untuk kelompok anak-anak balita.

Tabel 8 menunjukkan sebaran konsumsi lauk pauk. Sebagian besar masyarakat lebih sering mengonsumsi ikan asin, telur, dan tahu/ tempe, mungkin karena harganya yang relatif murah. Secara keseluruhan, konsumsi laukpauk di lokasi kontrol ataupun intervensi dapat dikatakan hampir sama. Konsumsi daging lebih menonjol pada masyarakat di lokasi kontrol. Mencermati data baseline dan endline, terlihat adanya penurunan jumlah rumah tangga yang mengonsumsi lauk pauk baik pada kelompok kontrol maupun intervensi. Namun penurunannya lebih tinggi pada kelompok kontrol dibandingkan pada kelompok intervensi.

Tabel 9 menunjukkan kebiasaan mengonsumsi lauk pauk di kalangan anak balita (seminggu terakhir). Kurang lebih sepertiga

Tabel 7. Jumlah Keluarga Ibu Balita menurut Kebiasaan Minum Susu

\begin{tabular}{lcccccc}
\hline \multirow{3}{*}{ Keluarga Ibu Balita } & \multicolumn{3}{c}{ Kontrol } & \multicolumn{3}{c}{ Intervensi } \\
\cline { 2 - 7 } & Awal & Akhir & Delta & Awal & Akhir & Delta \\
\cline { 2 - 7 } & $\%$ & $\%$ & $\%$ & $\%$ & $\%$ & $\%$ \\
\hline - Anak di bawah 5 tahun & 63.3 & 50.0 & -13.3 & 50.4 & 55.0 & 4.6 \\
- Semua anak & 21.7 & 19.2 & -2.5 & 13.4 & 14.3 & 0.9 \\
- Ayah & 12.5 & 9.2 & -3.3 & 5.0 & 5.0 & 0.0 \\
- Ibu & 9.2 & 9.2 & 0.0 & 4.2 & 5.9 & 1.7 \\
- Semua anggota keluarga & 5.8 & 6.7 & 0.9 & 3.4 & 5.2 & 1.8 \\
\hline
\end{tabular}

Tabel 8. Jumlah Keluarga menurut Lauk Pauk yang Sering Dikonsumsi Keluarga Ibu Balita

\begin{tabular}{lcccccc}
\hline \multirow{2}{*}{ Lauk Pauk } & \multicolumn{3}{c}{ Kontrol } & \multicolumn{3}{c}{ Intervensi } \\
\cline { 2 - 7 } & Awal & Akhir & Delta & Awal & Akhir & Delta \\
\cline { 2 - 7 } & $\%$ & $\%$ & $\%$ & $\%$ & $\%$ & $\%$ \\
\hline - Ikan asin & 85.0 & 60.0 & -25.0 & 86.7 & 70.0 & -16.7 \\
- Ikan segar & 38.3 & 20.8 & -17.5 & 23.3 & 20.8 & -2.5 \\
- Telur & 83.3 & 66.7 & -16.6 & 82.5 & 77.5 & -5.0 \\
- Daging & 30.0 & 14.2 & -15.8 & 6.7 & 9.2 & -2.5 \\
- Tahu/Tempe & 98.3 & 74.2 & -24.1 & 96.7 & 78.3 & -18.4 \\
\hline
\end{tabular}

Tabel 9. Jumlah Keluarga menurut Pangan yang Dikonsumsi Balita (dari Keluarga Non Kader) dalam Satu Minggu Terakhir

\begin{tabular}{|c|c|c|c|c|c|c|}
\hline \multirow{3}{*}{ Lauk Pauk } & \multicolumn{3}{|c|}{ Kontrol } & \multicolumn{3}{|c|}{ Intervensi } \\
\hline & Awal & Akhir & Delta & Awal & Akhir & Delta \\
\hline & $\%$ & $\%$ & $\%$ & $\%$ & $\%$ & $\%$ \\
\hline - Hati & 33.3 & 30.8 & -2.5 & 25.0 & 34.2 & 9.2 \\
\hline - Daging & 43.3 & 35.0 & -8.3 & 19.2 & 34.2 & 15.0 \\
\hline - Telur & 84.2 & 75.8 & -8.4 & 90.8 & 82.5 & -8.3 \\
\hline - Ikan & 62.5 & 55.0 & -7.5 & 65.8 & 53.3 & -12.5 \\
\hline - Tempe & 85.8 & 78.3 & -7.5 & 92.5 & 81.7 & -10.8 \\
\hline - Tahu & 89.2 & 78.3 & -10.9 & 89.2 & 80.0 & -9.2 \\
\hline
\end{tabular}


anak (di lokasi kontrol dan intervensi) yang mengonsumsi hati dan daging, sedangkan yang mengonsumsi telur, ikan, tahu, dan tempe jumlahnya lebih banyak. Berdasarkan data baseline dan endline terlihat adanya perbaikan (peningkatan jumlah anak yang mengonsumsi) pada kelompok intervensi terutama untuk konsumsi hati dan daging. Untuk pangan lainnya (telur, ikan, tempe, dan tahu) umumnya terjadi penurunan (pada kedua lokasi). Di dalam intervensi penyuluhan gizi telah ditekankan pentingnya asupan gizi yang bersumber pada pangan hewani untuk menjamin tumbuh kembang anak. Namun, upaya penyuluhan harus terusmenerus dilakukan agar perubahan praktek gizi menuju arah yang lebih baik dapat segera terwujud.

Tabel 10 menunjukkan jenis jajanan yang biasa dikonsumsi anak balita. Jajanan yang populer dan harganya murah adalah bakso, chiki, gorengan, dan permen. Jajan adalah fenomena umum bagi anak-anak di Indonesia, bahkan sejak usia balita mereka sudah biasa mengonsumsi jajanan. Hal ini terkadang memunculkan masalah makan bagi anak-anak balita, karena mereka terlalu banyak mengonsumsi makanan jajanan dan akhirnya tidak mau makan. Padahal makan akan memberikan kontribusi asupan energi dan protein yang lebih nyata dibandingkan jajan. Membandingkan data baseline dan endline terlihat adanya peningkatan jumlah anak balita yang diberi jajanan oleh orang tuanya. Persentasenya hampir sama antara kelompok kontrol dan intervensi. Kiranya agak sulit mengubah perilaku jajan di kalangan anak-anak. Masih diperlukan waktu lama untuk menanamkan kesadaran bagi orang tuanya agar tidak lagi membiasakan jajan bagi anak-anaknya.

\section{Faktor-faktor yang Berpengaruh terhadap Pengetahuan, Sikap dan Praktek Gizi}

Berdasarkan hasil analisis GLM, intervensi berupa penyuluhan pangan dan gizi serta program tanaman pekarangan yang dilakukan selama lima bulan berpengaruh nyata terhadap peubah respon pengetahuan, sikap dan praktek gizi Ibu seperti ditunjukkan oleh Tabel 11, Tabel 13 dan Tabel 15. Untuk mengurangi error terhadap peubah respon, telah dimasukkan pengetahuan, sikap dan praktek gizi awal (baseline) dan lokasi sebagai blok ke dalam model GLM. Ternyata pengetahuan gizi awal berpengaruh nyata terhadap pengetahuan gizi akhir. Demikian pula sikap gizi awal berpengaruh nyata terhadap sikap gizi akhir. Namun praktek gizi awal tidak berpengaruh nyata terhadap praktek gizi akhir. Blok atau lokasi tidak berpengaruh nyata terhadap ketiga peubah respon tersebut, atau dengan kata lain pengetahuan, sikap dan praktek gizi ibu tidak berbeda antara ibu yang tinggal di Darmaga ataupun Ciomas.

Adanya pengaruh yang nyata intervensi terhadap peubah respon tersebut menunjukkan bahwa model GLM yang dibangun sudah cukup tepat. Model GLM untuk pengetahuan gizi memberikan koefisien determinasi sebesar $\mathrm{R}^{2}=77.34 \%$. Koefisien ini menunjukkan bahwa model yang terdiri atas intervensi dan pengetahuan gizi awal serta blok dapat menjelaskan keragaman pengetahuan gizi ibu sebesar 77.34\%. Dengan uji lanjut Duncan diperoleh hasil bahwa rata-rata pengetahuan gizi ibu yang mendapat intervensi (skor 73.3) lebih besar secara nyata daripada rata-rata pengetahuan gizi ibu kontrol (skor 56.25). Dengan kata

Tabel 10. Jumlah Keluarga menurut Jajanan yang biasa Diberikan Pada Balita

\begin{tabular}{lcccccc}
\hline \multirow{2}{*}{ J Jajanan } & \multicolumn{3}{c}{ Kontrol } & \multicolumn{3}{c}{ Intervensi } \\
\cline { 2 - 7 } & Awal & Akhir & Delta & Awal & Akhir & Delta \\
\cline { 2 - 7 } & $\%$ & $\%$ & $\%$ & $\%$ & $\%$ & $\%$ \\
\hline - Bakso & 61.7 & 84.2 & 22.5 & 66.4 & 92.4 & 26.0 \\
- Chiki & 68.3 & 87.5 & 19.2 & 75.8 & 89.9 & 14.1 \\
- Gorengan & 68.3 & 95.0 & 26.7 & 70.0 & 95.0 & 25.0 \\
- Permen & 65.0 & 83.3 & 18.3 & 74.2 & 92.4 & 18.2 \\
\hline
\end{tabular}

Tabel 11. Sidik Ragam Pengetahuan Gizi Ibu

\begin{tabular}{lcrrrr}
\hline \multicolumn{1}{c}{ Sumber Keragaman } & $\mathrm{db}$ & \multicolumn{1}{c}{ JK } & \multicolumn{1}{c}{ KT } & F Hitung & Probabilitas \\
\hline Blok & 1 & 91.94578766 & 91.94578766 & 1.66 & 0.2214 \\
Perlakuan & 1 & 940.83214824 & 940.83214824 & 17.03 & 0.0014 \\
Pengetahuan Gizi lbu Awal & 1 & 731.72261315 & 731.72261315 & 13.24 & 0.0034 \\
Error & 12 & 663.11603685 & 55.25966974 & & \\
Total & 15 & 2925.96910000 & & & \\
& $\mathrm{R}^{2}$ & 0.773369 & & & \\
\hline
\end{tabular}


Tabel 12. Uji Duncan Pengetahuan Gizi Ibu menurut Lokasi (blok) atau Perlakuan

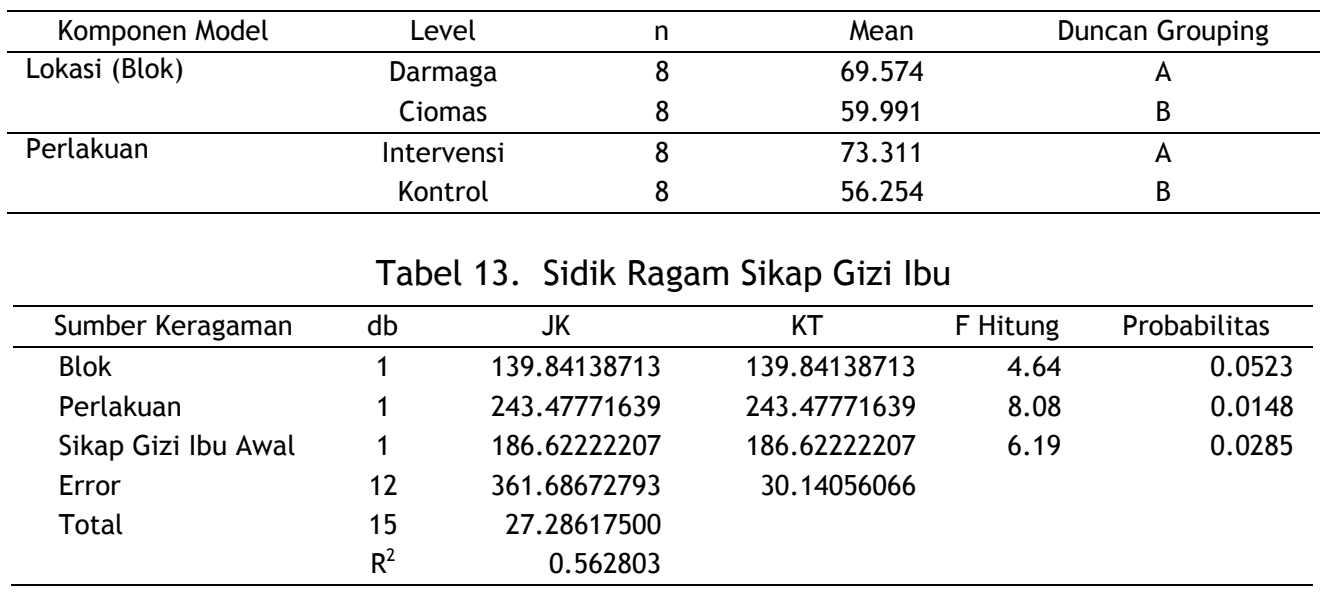

Tabel 14. Uji Duncan Sikap Gizi Ibu menurut Lokasi (Blok) atau Perlakuan

\begin{tabular}{ccccc}
\hline Komponen Model & Level & $\mathbf{n}$ & Mean & Duncan Grouping \\
\hline Lokasi (Blok) & Dramaga & 8 & 6.000 & $\mathrm{~A}$ \\
& Ciomas & 8 & 71.083 & $\mathrm{~A}$ \\
\hline Perlakuan & Intervensi & 8 & 76.916 & $\mathrm{~A}$ \\
& Kontrol & 8 & 70.166 & $\mathrm{~B}$ \\
\hline
\end{tabular}

Tabel 15. Sidik Ragam Praktek Gizi Ibu

\begin{tabular}{lcrrrr}
\hline Sumber Keragaman & db & \multicolumn{1}{c}{ J K } & \multicolumn{1}{c}{ KT } & F Hitung & Probabilitas \\
\hline Blok & 1 & 6.54128038 & 6.54128038 & 3.70 & 0.0783 \\
Perlakuan & 1 & 14.89031980 & 14.89031980 & 8.43 & 0.0132 \\
Praktek Gizi lbu Awal & 1 & 7.56292063 & 7.56292063 & 4.28 & 0.0608 \\
Error & 12 & 21.19451062 & 1.76620922 & & \\
Total & 15 & 43.36384375 & & & \\
& $\mathrm{R}^{2}$ & 0.511240 & & & \\
\hline
\end{tabular}

Tabel 16. Uji Duncan Praktek Gizi Ibu menurut Lokasi (Blok) atau Perlakuan

\begin{tabular}{ccccc}
\hline Komponen Model & Level & $\mathbf{n}$ & Mean & Duncan Grouping \\
\hline Lokasi (Blok) & Dramaga & 8 & 54.6650 & $\mathrm{~A}$ \\
& Ciomas & 8 & 53.5388 & $\mathrm{~A}$ \\
\hline Perlakuan & Intervensi & 8 & 54.8738 & $\mathrm{~A}$ \\
& Kontrol & 8 & 53.3300 & $\mathrm{~B}$ \\
\hline
\end{tabular}

lain intervensi dapat meningkatkan pengetahuan gizi ibu sebesar 17 poin.

Model GLM untuk sikap gizi ibu memberikan koefisien determinasi sebesar $\mathrm{R}^{2}=56.28 \%$. Hal ini berarti bahwa $56.28 \%$ keragaman sikap gizi ibu dapat dijelaskan oleh model yang terdiri atas intervensi, sikap gizi awal ibu dan blok. Hasil uji Duncan menunjukkan bahwa rata-rata sikap gizi ibu yang mendapat intervensi (skor 76.92) lebih besar secara nyata daripada rata-rata sikap gizi ibu kontrol (skor 70.12). Dengan demikian dapat dikatakan bahwa intervensi dapat meningkatkan sikap gizi ibu sebesar 6 poin.

Sebesar $51.12 \%$ keragaman praktek gizi ibu dapat dijelaskan oleh model GLM seperti ditunjukkan oleh koefisien diterminasi $\mathrm{R}^{2}$. Ha- sil uji Duncan menunjukkan bahwa rata-rata praktek gizi ibu (skor 54.87) lebih besar secara nyata daripada rata-rata praktek gizi ibu kontrol (skor 53.33). Nampaknya intervensi dapat meningkatkan praktek gizi ibu sebesar 1.5 poin. Dapat dipahami bahwa meningkatkan praktek gizi ibu adalah yang paling sulit dibandingkan meningkatkan pengetahuan atau sikap gizi ibu. Praktek gizi mungkin juga dipengaruhi oleh daya beli seseorang.

\section{Perilaku Hidup Sehat Ibu dan Anak}

Perilaku masyarakat menuju Indonesia Sehat 2010 yang diharapkan adalah yang bersifat proaktif untuk memelihara dan meningkatkan kesehatan, mencegah dan melindungi diri dari ancaman penyakit serta berpartisipasi ak- 
tif dalam berbagai kegiatan yang mengarah pada perbaikan kesehatan masyarakat. Setiap keluarga diharapkan mampu mendeteksi masalah kesehatan serta mengambil langkah-langkah untuk mengatasi masalah kesehatan tersebut dengan menggunakan sumber daya yang ada (Azwar, 2004).

Perilaku hidup sehat keluarga tercermin dari perilaku hidup sehat ibu dan anak pada umumnya. Perilaku hidup sehat yang dilakukan oleh ibu di desa kontrol dan intervensi relatif sama. Sebagian besar ibu di desa kontrol (95.0\%) dan desa intervensi (94.5\%) telah biasa memandikan anak dengan menggunakan sabun mandi. Kebiasaan ibu memotong kuku anak setiap minggu juga sudah dilakukan (di desa kontrol sebesar $77.5 \%$ dan di desa intervensi sebesar 65.6\%).

Perilaku hidup sehat yang juga sudah dilakukan adalah mencuci rambut anak tiga kali setiap minggu (di desa kontrol 69.2\% dan di desa intervensi 67.0). Dalam perilaku menggosok gigi dan memulainya pada usia dini masih banyak ibu yang belum melaksanakannya. Di desa kontrol ibu yang membiasakan anak menggosok gigi dua kali dalam sehari $49.5 \%$ sedangkan di desa intervensi sedikit lebih tinggi yaitu mencapai $51.0 \%$. Demikian pula halnya dengan perilaku menggosok gigi pada usia dini, di desa kontrol sebesar $15.2 \%$ dan di desa intervensi sedikit lebih tinggi yaitu $22.0 \%$.

Perilaku hidup sehat mencuci kaki sebelum tidur, menggosok gigi dengan pasta gigi, dan memakai alas kaki kalau berada di luar rumah anak di kedua desa masih sangat rendah. Di desa kontrol sebanyak $65.8 \%$ anak sudah membiasakan diri mencuci kaki sebelum tidur dan di desa intervensi sebesar $61.5 \%$. Kegiatan menggosok gigi menggunakan pasta gigi dilakukan oleh sebanyak $57.0 \%$ anak di desa kontrol dan di desa intervensi sedikit lebih banyak yaitu sebesar $62.9 \%$. Sedangkan dalam hal kebiasaan memakai alas kaki kalau berada di luar rumah, anak di desa kontrol sebanyak $60.9 \%$ sudah melakukan dan anak di desa intervensi sebesar $56.4 \%$.

Perilaku hidup sehat lain yang masih kurang dilakukan anak adalah membiasakan mencuci tangan sesudah BAB (di desa kontrol, hanya dilakukan oleh $14.5 \%$ anak dan di desa intervensi oleh $18.4 \%$ anak). Sebesar $41.7 \%$ anak di desa kontrol dan $48.2 \%$ di desa intervensi telah mempunyai kebiasaan mencuci tangan menggunakan sabun. Sedangkan tentang kebiasaan mencuci tangan sebelum makan, sebesar $44.1 \%$ anak di desa kontrol dan $42.6 \%$ di desa intervensi sudah melakukannya. Kalau dilihat secara keseluruhan perilaku sehat ibu dan anak di desa intervensi sedikit lebih baik bila dibandingkan dengan perilaku hidup sehat ibu dan anak di desa kontrol.

\section{KESIMPULAN}

Berdasarkan analisis General Linear Model (GLM), intervensi dalam bentuk pendidikan gizi dan pemanfaatan pekarangan yang dilakukan selama lima bulan berpengaruh nyata terhadap pengetahuan gizi, sikap, dan praktek gizi ibu.

Pada kelompok kontrol, skor awal (baseline data) pengetahuan gizi ibu adalah 37.1 dan skor akhir (endline data) adalah 34.9. Terdapat penurunan skor sebanyak 2.3 poin. Skor pada kelompok intervensi meningkat dari $\mathbf{4 6 . 0}$ (baseline) menjadi 52.6 (endline) atau meningkat sebanyak 7.5 poin.

Skor sikap gizi ibu menunjukkan bahwa ketika kedua data (baseline dan endline) pada kelompok kontrol dibandingkan, terlihat bahwa terdapat penurunan skor dari 73.8 menjadi

Tabel 17. Sebaran Perilaku Hidup Sehat Ibu dan Anak

\begin{tabular}{lcccc}
\hline \multicolumn{1}{c}{ Peubah } & \multicolumn{2}{c}{ kontrol } & \multicolumn{2}{c}{ Intervensi } \\
\cline { 2 - 5 } & $\mathbf{n}$ & $\%$ & $\mathbf{n}$ & \% \\
\hline Ibu biasa memandikan anak dgn sabun mandi & 114 & 95.0 & 112 & 94.9 \\
Ibu biasa menggosok gigi anak > 2 kali/hari & 53 & 49.5 & 53 & 51.0 \\
Ibu membiasakan anak gosok gigi usia $<1$ th & 14 & 15.2 & 20 & 22.0 \\
Ibu biasa mencuci rambut anak > 3 kali/mg & 83 & 69.2 & 79 & 67.0 \\
Ibu biasa memotong kuku anak setiap minggu & 93 & 77.5 & 76 & 65.6 \\
Anak biasa mencuci kaki sebelum tidur & 79 & 65.8 & 72 & 61.5 \\
Anak menggosok gigi dengan pasta gigi & 61 & 57.0 & 61 & 62.9 \\
Anak mencuci tangan setelah BAB dg sabun & 17 & 14.5 & 20 & 18.4 \\
Anak biasa memakai sandal diluar rumah & 67 & 60.9 & 62 & 56.4 \\
Anak mencuci tangan sebelum makan & 45 & 44.1 & 46 & 42.6 \\
Anak mencuci tangan menggunakan sabun & 45 & 41.7 & 53 & 48.2 \\
\hline
\end{tabular}


70.2 (turun 3.7 poin). Pada kelompok intervensi, terdapat peningkatan skor yaitu dari 71.8 menjadi 76.9 (meningkat 5.1 poin).

Praktek gizi dicerminkan oleh kebiasaan sarapan pagi, ketersediaan buah di rumah, konsumsi lauk pauk, penggunaan garam beryodium, dan lainnya. Pada kedua kelompok (kontrol dan intervensi), persentase anak yang biasa sarapan pagi lebih tinggi daripada orang tuanya. Pada data baseline dan endline, persentase anggota keluarga (ayah, ibu, dan anak) pada kelompok intervensi yang membiasakan diri sarapan pagi adalah lebih dari $80.0 \%$, berbeda dengan kelompok kontrol, persentasenya antara $55.0 \%$ hingga $77.5 \%$. Pada umumnya, jumlah anak yang makan tiga kali sehari lebih tinggi daipada orang tuanya. Kebiasaan mengonsumsi lauk-pauk pada anak menunjukkan bahwa dari data baseline dan endline terdapat peningkatan jumlah anak mengonsumsi lauk-pauk (hati dan daging) pada kelompok intervensi. Terdapat penurunan konsumsi pangan lain seperti telur, ikan, tempe, dan tahu pada kedua kelompok.

\section{DAFTAR PUSTAKA}

Azwar A. 2004. Aspek Kesehatan dan Gizi dalam Ketahanan Pangan. Dalam Soekirman dkk. (Eds.), Ketahanan Pangan dan Gizi di Era Otonomi Daerah dan Globalisasi. Prosiding Widyakarya Nasional Pangan dan Gizi VIII (hlm. 101109), 17-19 Mei. LIPI, Jakarta.

Kardjati S, Alisjahbana A, \& Kusin JA. 1985. Nutrition and Health of Children Under Five Years Old. Yayasan Obor Anak Indonesia, Jakarta.

Sediaoetama AD. 1996. Gizi: untuk Mahasiswa dan Profesional (I). Dian Rakyat, Jakarta.

Suhardjo. 1989. Berbagai Cara Pendidikan Gizi. Depdikbud - PAU Pangan dan Gizi, IPB, Bogor. 